\title{
Scientific Basis for the Treatment and Prevention of Large Abdominal Acidosis in Productive Cows
}

\author{
Bekjon Norbek Ogli Khayitov; Bakhtiyar Bakirov²; Nuriddin Bollievich Ruzikulov ${ }^{3}$ \\ ${ }^{1} \mathrm{PhD}$ Student, Samarkand Institute of Veterinary Medicine, Uzbekistan \\ ${ }^{2}$ Professor, Samarkand Institute of Veterinary Medicine, Uzbekistan \\ ${ }^{3}$ Associate Professor, Samarkand Institute of Veterinary Medicine, Uzbekistan
}

http://dx.doi.org/10.18415/ijmmu.v8i9.3063

\begin{abstract}
The article analyzes the results of clinical observations on the distribution and etiology, as well as experimental studies on the development of diagnostic and treatment-and-prophylactic measures of rumen acidosis in breeding cows in the conditions of farms of the republic.
\end{abstract}

Keywords: Acidosis; Laminite, Lactic Acid and UCA; Large Abdominal Fluid Environment (PH); In Chronic Acidosis of the Large Abdomen (ACSA)

\section{Introduction}

Diseases of imported pedigree cattle, in particular, diseases of digestion and metabolism, are one of the major obstacles to the implementation of agrarian reforms in the country and cause great economic damage to livestock.

Currently, due to the fact that the rations of livestock farms in the feeding of high-yielding cows are of a high concentrate type and lack of quality hay, there is a large abdominal acidosis due to diseases of the digestive system of livestock, including the anterior gastrointestinal tract.

It is known that high productivity of modern pedigree cows occurs as a result of well-balanced (primarily in terms of energy and protein) feeding. The peculiarity of feeds is that a steady increase in starch-rich grain concentrates and a decrease in the amount of nutrients rich in quality hay, high concentrate feeding leads to disruption of gastric fermentation and acidosis, as well as laminitis and other diseases with increased milk production. This is due to the intensive formation of a number of acids in the large intestine, including lactic acid, and the increase in starch fermentation, which leads to a decrease in the $\mathrm{pH}$ of the large intestine to 5.2-5.6 (in healthy animals $=6.5-7.5$ ) $[1]$.

Wheat, which currently makes up the bulk of concentrated foods, is quickly converted to lactic acid and UCO and fermented rapidly. Corn and oats are fermented slowly [2]. Therefore, diets high in wheat and barley pose a greater risk of acidosis than diets high in corn and oats. Despite the fact that there is 
enough research by scientists around the world on the timely diagnosis, effective treatment and prevention of such diseases, different nutritional conditions; as well as the geo-ecological and endemic features of the place and the types and peculiarities of diseases of the anterior gastrointestinal tract in productive cattle by season, the effective diagnostic, treatment and prevention methods against them have not been developed. Therefore, to determine the nature of digestive processes in the anterior sections of productive cattle and the causes of disruption of these processes; scientific studies aimed at substantiating the dominant role of such disorders in metabolism, as well as the importance of laboratory tests of large abdominal fluid in the diagnosis of diseases of the anterior gastrointestinal tract are very relevant.

The purpose of the study. Early detection, effective treatment and development of a set of group prevention measures for large abdominal acidosis and metabolic disorders associated with this disease in pedigree cattle.

Object and methods of research. The research was conducted at "Agrabravo Chorvasi" farm in Aqdarya district of Samarkand region, "Ochilov Mahmudjon Dalasi" farm in Payarik district and "Yangi Asr" livestock farm in Kyzyltepa district of Navoi region. Clinical and laboratory examinations were carried out on the basis of the principle of medical examination of 30 cows at the farm "Agrabravo Chorvasi", 5 cows at the farm "Ochilov Mahmudjon Dalasi", 10 cows at the farm "Yangi Asr".

Analysis of the obtained results. Studies have shown that the incidence of large abdominal acidosis depends mainly on the age of 3-4 cows, i.e. the calving period, as well as the fact that there is a difference in the diet of cows with carcasses.

According to the scientist's observations, large abdominal acidosis often manifests itself in 3-4 months after the birth of the animal and then throughout the year, which leads to the treatment of animals [6].

\section{The Main Findings and Results}

The results of the study showed that in cows in the last months of gestation and during lactation, the environment $(\mathrm{pH})$ in the large abdominal fluid shifts to acidity, the number of infusoria decreases relative to physiological norms, and their mobility decreases. The disease is acute in the last month of pregnancy and the first month of lactation, moderate in the second and third months, and chronic in the rest of lactation. This is due to the lack of active mats in cows, silage-concentrate type of cow's diet, low sugarprotein ratio, the content of fatty acids in corn silage, which is the main part of the diet, averaging $1.2 \%$ (the norm is $0.1-0.3 \%$ and can be explained by the occurrence of acidosis. I.P.Kondrakhin, V.I.Levchenko, (2005) of these data. Consistent with the results of research by Y.T. Khmelkov (2000).

Clinical trials determined the body temperature, respiratory rate, pulse, movement of the large abdominal wall, mucous membranes, liver border, and its reaction on palpation in cows (Table 1). 
Table 1. Results of clinical examination of experimental cows $(M \pm m ; N=10)$

\begin{tabular}{|c|c|c|c|c|c|c|c|c|c|}
\hline $\begin{array}{c}\text { Business } \\
\text { name }\end{array}$ & 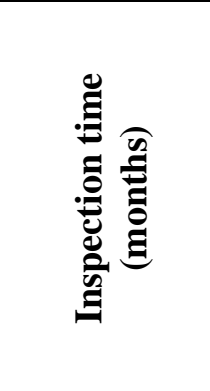 & 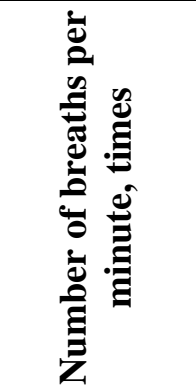 & 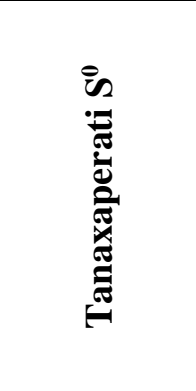 & 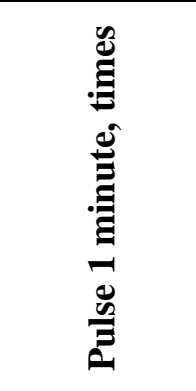 & 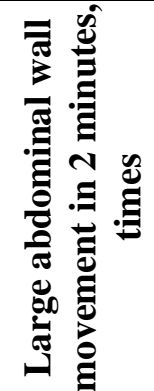 & 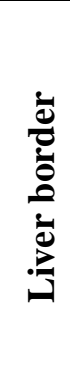 & 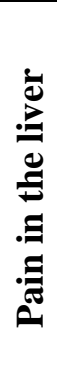 & 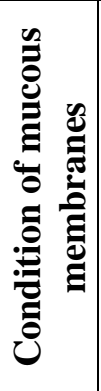 & $\frac{\stackrel{0}{0}}{\frac{0}{0}}$ \\
\hline \multirow{2}{*}{\begin{tabular}{|c|} 
Ochilov \\
Mahmudjon \\
field farm \\
\end{tabular}} & 3 births & \multirow[b]{2}{*}{$12,4 \pm 0,46$} & \multirow[b]{2}{*}{$38,1 \pm 0,18$} & \multirow[b]{2}{*}{$54,32 \pm 2,63$} & \multirow[b]{2}{*}{$1,4 \pm 0,14$} & \multirow[b]{2}{*}{+-} & \multirow[b]{2}{*}{ - } & \multirow[b]{2}{*}{+-} & \multirow[b]{2}{*}{+} \\
\hline & $\begin{array}{c}4 \text { months of } \\
\text { lactation }\end{array}$ & & & & & & & & \\
\hline \multirow[b]{2}{*}{$\begin{array}{l}\text { Agrobravo } \\
\text { cattle farm }\end{array}$} & 2 births & \multirow[b]{2}{*}{$15,4 \pm 0,57$} & \multirow[b]{2}{*}{$37,84 \pm 0,14$} & \multirow[b]{2}{*}{$72,12 \pm 2,69$} & \multirow[b]{2}{*}{$1,2 \pm 0,22$} & \multirow[b]{2}{*}{+-} & \multirow[b]{2}{*}{ - } & \multirow[b]{2}{*}{+-} & \multirow[b]{2}{*}{$\begin{array}{l}+ \\
-\end{array}$} \\
\hline & $\begin{array}{c}5 \text { months of } \\
\text { lactation }\end{array}$ & & & & & & & & \\
\hline \multirow[t]{2}{*}{$\begin{array}{c}\text { New century } \\
\text { pet farm }\end{array}$} & $\begin{array}{c}3 \text { births } \\
2 \text { months of } \\
\text { lactation }\end{array}$ & $24,57 \pm 2,84$ & $38,6 \pm 0,15$ & $73,57 \pm 2,99$ & $\begin{array}{c}2,14 \pm 0,1 \\
8\end{array}$ & +- & - & +- & $\begin{array}{l}+ \\
-\end{array}$ \\
\hline & $\mathrm{P}<$ & 0,05 & 0,05 & 0,05 & 0,01 & & & & \\
\hline
\end{tabular}

Note: Liver border: + not enlarged, + - enlarged; Appetite: + good, + - decreased, - lost; Condition of mucous membranes: - not yellowed, + - partially yellowed, + + strongly yellowed; whether there is pain in the liver: - no, + there is.

Laboratory tests revealed the $\mathrm{pH}$ of the large abdominal fluid, the number of infusoria, the species composition of the infusoria, and the functional activity of the microorganisms (Table 2).

Volatile fatty acids (VOCs) are rarely used when lactic acid is increased in the large abdomen of cattle because it takes 3-4 weeks for the Megasphaera elsdenii bacterium involved in VOCs synthesis to multiply in the large intestine, and 2-3 days for lactic acid bacteria to multiply. Thus, when the amount of concentrates in the diet is higher than the rate of growth of lactic acid bacteria, lactic acid accumulates in the large abdomen, lowering the $\mathrm{pH}$ and the amount of VOCs.

Several groups of bacteria in the large abdomen (Megasphaera elsdenii, S. ruminantum) use fermented lactic acid for the synthesis of propionic acid, which prevents the accumulation of lactic acid in the large abdomen and thus normalizes the $\mathrm{pH}$ of the large abdomen [5].

The results of laboratory tests of blood samples from experimental cows are given in Table 3.

The table shows that the clinical performance of cows reared on all three farms, as well as the results of laboratory tests of large abdominal fluid, indicate the presence of chronic metabolic acidosis in cows.

Data from foreign researchers have shown a difference between acute, moderate, and chronic acidosis. In acute acidosis, the $\mathrm{pH}$ of the large abdomen is below 5.2, on average - the $\mathrm{pH}$ is in the range of 5.2 to 5.5. In chronic acidosis of the large abdomen (CALA), the figure ranges from 5.6 to 6.0. Unlike CALA during acute metabolic acidosis, the $\mathrm{pH}$ level can return to normal within a few hours [3].

He noted that the maintenance of the $\mathrm{pH}$ level for at least 3 hours, above 5.6, indicates the presence of chronic acidosis in animals. When the $\mathrm{pH}$ level decreases, the activity of the large abdominal microflora decreases, the appetite of cows decreases, the temperature rises, diarrhea (diarrhea), lameness (laminitis), enlargement of the liver, tympanum and sudden death are observed. 
According to the traditional method of treatment of acute and moderate stages of the disease of large abdominal acidosis of cows (Acidosis ruminis), cows are initially fasted for 6 hours. The stomach is washed with a 3\% sodium bicarbonate solution using a probe and 1-2 liters of healthy animal cataract fluid is ingested. On the left side every 4-5 hours for 10-15 minutes rubbed counterclockwise 1-2 times a day. Drink $10 \mathrm{ml}$ of chemiritsa tincture diluted in $500 \mathrm{ml}$ of water. Intravenous administration of a complex hypertonic solution ( $200 \mathrm{ml}$ of $5 \%$ sodium chloride, $200 \mathrm{ml}$ of $40 \%$ glucose, $10 \mathrm{ml}$ of ascorbic acid, $10 \mathrm{ml}$ of B complex vitamins, and $1 \mathrm{ml}$ of $20 \%$ caffeine) is administered intravenously. Antibiotics in the amount of 5-10 thousand XB/kg are used. $200 \mathrm{ml}$ of alcohol-yeast mixture is drunk 2 times a day. An active trip is scheduled. Quality raw foods are included in the diet (Bakirov B., 2015) [4].

Table 2. Results of laboratory testing of large abdominal fluid samples in experimental cows $(M \pm$ m; $\mathbf{N}=\mathbf{1 0}$ )

\begin{tabular}{|c|c|c|c|c|c|c|c|c|c|c|c|c|}
\hline \multirow[b]{2}{*}{ Business name } & \multirow{2}{*}{ 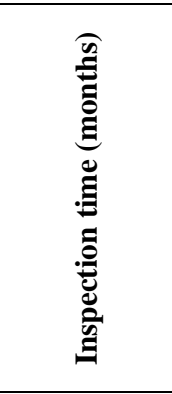 } & \multirow[b]{2}{*}{ T: } & \multirow{2}{*}{ 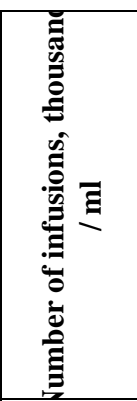 } & \multicolumn{4}{|c|}{$\begin{array}{c}\text { Infusion type, } \\
100 \% \\
\end{array}$} & \multirow{2}{*}{ 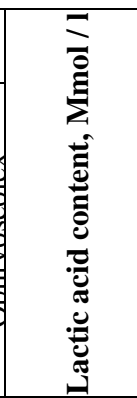 } & \multirow{2}{*}{ 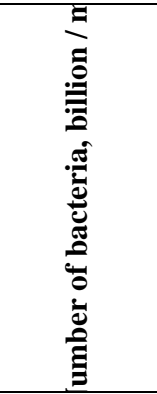 } & \multicolumn{2}{|c|}{$\begin{array}{c}\text { Bacterial } \\
\text { type, 100\% }\end{array}$} & \multirow{2}{*}{ 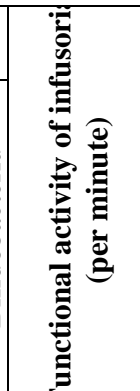 } \\
\hline & & & & 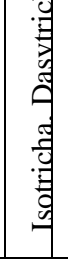 & 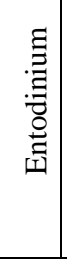 & 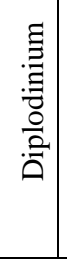 & $\begin{array}{l}\text { वे } \\
\text { व्. } \\
\text { 亲 }\end{array}$ & & & 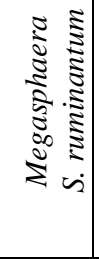 & 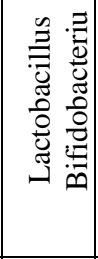 & \\
\hline $\begin{array}{l}\text { Ochilov Mahmudjon } \\
\text { dalasi farm }\end{array}$ & $\begin{array}{c}3 \text { Birth } \\
\begin{array}{c}\text { months of } \\
\text { lactation }\end{array}\end{array}$ & $5,85 \pm 0,2$ & $204 \pm 8,54$ & 2 & $51:$ & \begin{tabular}{l|l}
37 & 1
\end{tabular} & \multicolumn{2}{|c|}{$\begin{array}{ll}0 & 10,0 \pm 6,2\end{array}$} & $14,08 \pm 0,72$ & 8,73 & 91,27 & $26,0 \pm 0,5$ \\
\hline Agrobravo cattle farm & $\begin{array}{c}2 \text { Birth } \\
5 \text { months of } \\
\text { lactation }\end{array}$ & $5,76 \pm 0,4$ & $214 \pm 7,15$ & 1 & 54 & 38 & 7 & $9,0 \pm 0,5$ & $18,06 \pm 0,57$ & 7,11 & 92,89 & $32,0 \pm 0,87$ \\
\hline Yangi Asr farm & 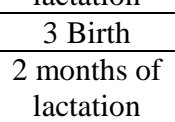 & $5,38 \pm 0,1$ & $254 \pm 5,6$ & 2,5 & \multirow[t]{2}{*}{58} & \multirow[t]{2}{*}{38} & \multicolumn{2}{|c|}{$5 \quad 7,0 \pm 0,75$} & $25,46 \pm 0,42$ & \multirow[t]{2}{*}{5,42} & 94,37 & $20,0 \pm 0,75$ \\
\hline $\overrightarrow{\mathrm{P}}<$ & & 0,01 & 0,05 & & & & & 0,01 & 0,05 & & & 0,05 \\
\hline
\end{tabular}

Table 3. Results of morpho-biochemical examination of blood samples of experimental cows (M \pm $\mathbf{m} ; \mathbf{N}=10$ )

\begin{tabular}{|c|c|c|c|c|c|c|c|}
\hline Business name & $\begin{array}{l}\text { Inspection time } \\
\text { (months) }\end{array}$ & $\begin{array}{c}\text { Hemoglobi } \\
\text { n, } \\
\text { g/l }\end{array}$ & $\begin{array}{c}\text { Number of } \\
\text { erythrocytes, } \\
\text { mln / } \mu \mathrm{l}\end{array}$ & $\begin{array}{c}\text { Glucose, Mmol } \\
\text { / 1 }\end{array}$ & $\begin{array}{c}\text { Total protein, } \\
\text { g / l }\end{array}$ & $\begin{array}{c}\text { Ketone } \\
\text { bodies, g / l }\end{array}$ & $\begin{array}{c}\text { Number of } \\
\text { leukocytes, } \\
\text { thousand / } \\
\text { ml }\end{array}$ \\
\hline \multirow{2}{*}{$\begin{array}{c}\text { Ochilov } \\
\begin{array}{c}\text { Mahmudjon dalasi } \\
\text { farm }\end{array}\end{array}$} & 3 Birth & \multirow[b]{2}{*}{$98,9 \pm 1,04$} & \multirow[b]{2}{*}{$4,84 \pm 0,02$} & \multirow[b]{2}{*}{$2,19 \pm 0,08$} & \multirow[b]{2}{*}{$54,94 \pm 1,22$} & \multirow[b]{2}{*}{$66,81 \pm 14,16$} & \multirow[b]{2}{*}{$10,54 \pm 0,81$} \\
\hline & 4 months of lactation & & & & & & \\
\hline \multirow{2}{*}{$\begin{array}{c}\text { Agrobravo cattle } \\
\text { farm } \\
\end{array}$} & 2 Birth & \multirow{2}{*}{$100,6 \pm 1,24$} & \multirow{2}{*}{$4,88 \pm 0,2$} & \multirow{2}{*}{$2,20 \pm 0,03$} & \multirow{2}{*}{$64,88 \pm 2,26$} & \multirow{2}{*}{$84,22 \pm 12,64$} & \multirow{2}{*}{$11,62 \pm 0,75$} \\
\hline & 5 months of lactation & & & & & & \\
\hline \multirow{2}{*}{ Yangi Asr farm } & 3 Birth & \multirow{2}{*}{$92,57 \pm 7,92$} & \multirow{2}{*}{$4,15 \pm 0,14$} & \multirow{2}{*}{$2,26 \pm 0,05$} & \multirow{2}{*}{$77,25 \pm 1,44$} & \multirow{2}{*}{$74,68 \pm 15,27$} & \multirow{2}{*}{$9,74 \pm 0,65$} \\
\hline & 2 months of lactation & & & & & & \\
\hline & $\mathrm{P}<$ & 0,05 & 0,01 & 0,01 & 0,05 & 0,05 & 0,05 \\
\hline
\end{tabular}

Experiments have shown that the use of the above treatments is appropriate in acute and moderate cases of large abdominal acidosis. However, among cows, the chronic stage of basal acidosis is mainly in $80-85 \%$ of cows with this disease on the farm, compared to the acute and moderate stages of the disease. Therefore, it has been found that age-appropriate experiments are needed to treat all stages of large abdominal acidosis. 
The experiments were carried out on Holstein cows bred on the farm "Agro Bravo Chorvasi" in Akdarya district of Samarkand region. Cows with large abdominal acidosis were isolated on the farm, each with 5 to 6 groups, and a total of 30 cows with acute, moderate, and chronic stages of the disease were selected, and experiments were continued for a total of 90 days. Cows were inspected at the beginning of the experiment and once every 30 days.

In addition to the traditional treatment methods mentioned above in the treatment of cows in this experiment, the following scientific experiments were performed.

The experimental scheme is given in Table 4, and the composition of the periparts used in the experiment is given in Table 5.

Table 4. Scheme of experiments in the treatment of large abdominal acidosis (Agro-Bravo cattleF / $\mathbf{x} ; \mathbf{M} \pm \mathbf{m} ; \mathbf{N}=\mathbf{3 0}$ )

\begin{tabular}{|c|c|c|c|c|c|c|c|c|c|}
\hline \multirow[b]{2}{*}{ 产 } & \multicolumn{9}{|c|}{ Experimental tools, 1 per 1 day } \\
\hline & $\begin{array}{l}\text { Farm } \\
\text { ration }\end{array}$ & $\begin{array}{l}\text { GELAMIN } \\
\text { Varioferm } \\
\text { 100, gram }\end{array}$ & $\begin{array}{l}\text { GELAMIN } \\
\text { Varioferm } \\
\text { 150, gram }\end{array}$ & $\mathrm{CCOC}$ & Mineral salts & $\begin{array}{c}\text { Alcoholic yeas } \\
\text { mixture }\end{array}$ & $\begin{array}{c}\text { Tea soda } \\
\left(\mathrm{NaHCO}_{3}\right)\end{array}$ & $\begin{array}{c}\text { Essential } \\
\text { forte }\end{array}$ & $\begin{array}{c}\text { Multivit + } \\
\text { minerals }\end{array}$ \\
\hline 1 & 2 & 3 & 4 & 5 & 6 & 7 & 9 & 10 & 11 \\
\hline I & + & & & & & & & & \\
\hline II & + & + & & & & & & & \\
\hline III & + & & + & & & & & & \\
\hline IV & + & & & + & & + & + & & \\
\hline $\mathbf{V}$ & + & + & & + & & + & + & & \\
\hline VI & + & + & & + & + & + & + & + & + \\
\hline
\end{tabular}

Table 5. Composition of drugs and nutritional supplements used in treatment and prevention experiments (Agro-Bravo cattleF / $\mathbf{x} ; \mathbf{M} \pm \mathbf{m} ; \mathbf{N}=30$ )

\begin{tabular}{|c|c|}
\hline \multicolumn{2}{|c|}{ PREMIX CONTENT } \\
\hline \multicolumn{2}{|c|}{ Organic matter\% } \\
\hline Crude protein & 13,8 \\
\hline Crude oil & 2,6 \\
\hline Raw fiber & 10,9 \\
\hline Raw ash & 4,6 \\
\hline \multicolumn{2}{|c|}{ Macro elements } \\
\hline Calcium & 0,5 \\
\hline Phosphorus & 0,5 \\
\hline Sodium & 0,1 \\
\hline Magnesium & 0,2 \\
\hline \multicolumn{2}{|c|}{ Microorganism content, per $100 \mathrm{~g}$} \\
\hline Saccharomycescerevisie & $0,9 * 10^{\wedge} 9$ \\
\hline Aspergiliusoryzae & 4 гр \\
\hline \multicolumn{2}{|c|}{ Tea soda $\left(\mathrm{NaHCO}_{3}\right)$} \\
\hline For therapeutic purposes & $50-55$ гр \\
\hline In order to prevent & 30-35 гр \\
\hline
\end{tabular}

\begin{tabular}{|c|c|}
\hline \multicolumn{2}{|c|}{ Mineral salts, 1 per 1 day } \\
\hline Ferrous sulfate & $1 \mathrm{~g}$ \\
\hline Mis sulfate & $100 \mathrm{mg}$ \\
\hline Koboly chloride & $10 \mathrm{mg}$ \\
\hline Manganese sulfate & $100 \mathrm{mg}$ \\
\hline Zinc sulfate & $100 \mathrm{mg}$ \\
\hline Ca iodine & $3 \mathrm{mg}$ \\
\hline \multicolumn{2}{|c|}{$\begin{array}{c}\text { Biostimulator aimed at restoring liver function } \\
1 \text { head per day }\end{array}$} \\
\hline Essential forte & 10 мл \\
\hline \multicolumn{2}{|c|}{1 head every 15 days } \\
\hline Multivit + minerals & 20 мл \\
\hline
\end{tabular}


Table 6. Results of morpho-biochemical examination of blood of experimental cows (Agro-Bravo cattleF / $x ; M \pm m ; N=30$ )

\begin{tabular}{|c|c|c|c|c|c|c|c|c|c|c|c|c|c|c|}
\hline \multirow[b]{3}{*}{ Groups } & \multirow[b]{3}{*}{ Check time } & \multirow[b]{3}{*}{ Hemoglobin, $\mathrm{g} / \mathrm{l}$} & \multirow{3}{*}{$\begin{array}{c}\text { Number of } \\
\text { erythrocytes, } \\
\mathrm{mln} / \boldsymbol{\mu l}\end{array}$} & \multirow[b]{3}{*}{$\begin{array}{l}\text { Glucose, } \\
\text { Mmol / I }\end{array}$} & \multirow[b]{3}{*}{ Total protein, g / } & \multirow[b]{3}{*}{$\begin{array}{l}\text { The amount of } \\
\text { ketone bodies, } \\
\text { g / l }\end{array}$} & \multirow[b]{3}{*}{$\begin{array}{l}\text { Number of } \\
\text { leukocytes, } \\
\text { thousand / ml }\end{array}$} & \multicolumn{7}{|c|}{ Лейкограмма, \% } \\
\hline & & & & & & & & \multirow[b]{2}{*}{ 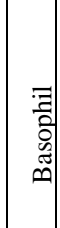 } & \multirow[b]{2}{*}{ 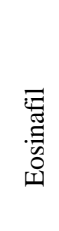 } & \multicolumn{3}{|c|}{ Нейтрофил } & \multirow{2}{*}{ 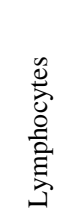 } & \multirow[b]{2}{*}{ 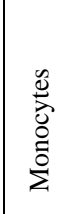 } \\
\hline & & & & & & & & & & $\underset{\infty}{\infty}$ & 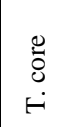 & $\begin{array}{l}0 \\
\dot{0} \\
\dot{s}\end{array}$ & & \\
\hline \multirow[t]{2}{*}{ Control I } & $\begin{array}{c}\text { The } \\
\text { beginning of } \\
\text { the } \\
\text { experiment } \\
\end{array}$ & $99,65 \pm 1,9$ & $4,87 \pm 0,04$ & $2,42 \pm 0,08$ & $65,13 \pm 1,04$ & $82,0 \pm 3,54$ & $7,46 \pm 0,08$ & 8,6 & 3,2 & 3,2 & 2,4 & 3,0 & 67,5 & 12,1 \\
\hline & 90 days & $98.92 \pm 1,4$ & $4,53 \pm 0,05$ & $2,20 \pm 0,045$ & $52,64 \pm 1,67$ & $99,0 \pm 4,25$ & $7,73 \pm 0,06$ & 8,8 & 3,4 & 3,3 & 3,6 & 3,5 & 66,2 & 11,2 \\
\hline \multirow[t]{2}{*}{ Control II } & $\begin{array}{c}\text { The } \\
\text { beginning of } \\
\text { the } \\
\text { experiment } \\
\end{array}$ & $99,42 \pm 1,8$ & $4,75 \pm 0,04$ & $2,28 \pm 0,08$ & $59,2 \pm 2,28$ & $85,0 \pm 2,88$ & $7,24 \pm 0,04$ & 8,5 & 4,0 & 3,6 & 3,7 & 4,2 & 65,5 & 10,5 \\
\hline & 90 days & $100,21 \pm 1,35$ & $5,03 \pm 0,06$ & $2,41 \pm 0,032$ & $73,14 \pm 1,9$ & $68,0 \pm 4,82$ & $7,99 \pm 0,08$ & 6,9 & 4,8 & 2,4 & 3,6 & 4,9 & 67,9 & 9,5 \\
\hline \multirow[t]{2}{*}{ Control III } & $\begin{array}{c}\text { The } \\
\text { beginning of } \\
\text { the } \\
\text { experiment } \\
\end{array}$ & $99,26 \pm 1,82$ & $4,66 \pm 0,03$ & $2,33 \pm 0,017$ & $58,67 \pm 1,20$ & $73,0 \pm 3,5$ & $8,14 \pm 0,08$ & 8,4 & 3,3 & 2,6 & 4,0 & 3,6 & 66,8 & 11,3 \\
\hline & 90 days & $100,83 \pm 1,45$ & $5,01 \pm 0,04$ & $2,48 \pm 0,04$ & $71,56 \pm 1,38$ & $64,0 \pm 5,54$ & $8,24 \pm 0,06$ & 7,6 & 3,9 & 2,3 & 3,1 & 4,6 & 68,6 & \begin{tabular}{|l|}
9,9 \\
\end{tabular} \\
\hline \multirow[t]{2}{*}{ Control IV } & \begin{tabular}{|c|} 
The \\
beginning of \\
the \\
experiment \\
\end{tabular} & $99,48 \pm 1,84$ & $4,81 \pm 0,04$ & $2,36 \pm 0,08$ & $61,37 \pm 1,23$ & $84,0 \pm 4,92$ & $7,62 \pm 0,02$ & 8,9 & 3,5 & 3,1 & 2,6 & 4,0 & 66,1 & 11,8 \\
\hline & 90 days & $98,74 \pm 1,29$ & $4,41 \pm 0,02$ & $2,23 \pm 0,035$ & $54,23 \pm 0,89$ & $77,0 \pm 4,63$ & $8,09 \pm 0,05$ & 7,1 & 4,3 & 2,5 & 3,2 & 8,6 & 64,9 & 9,4 \\
\hline \multirow[t]{2}{*}{ Control V } & $\begin{array}{c}\text { The } \\
\text { beginning of } \\
\text { the } \\
\text { experiment } \\
\end{array}$ & $99,28 \pm 1,53$ & $4,79 \pm 0,06$ & $2,29 \pm 0,05$ & $65,14 \pm 2,95$ & $93,0 \pm 6,45$ & $7,92 \pm 0,07$ & 8,2 & 3,8 & 3,3 & 3,4 & 3,7 & 6,5 & 11,1 \\
\hline & 90 days & $101,27 \pm 1,32$ & $5,02 \pm 0,02$ & $2,64 \pm 0,02$ & $75,12 \pm 0,31$ & $58,0 \pm 3,26$ & $8,18 \pm 0,02$ & 4,1 & 4,7 & 1,9 & 3,6 & 11,8 & 65,5 & 8,4 \\
\hline \multirow[t]{2}{*}{ Control VI } & $\begin{array}{c}\text { The } \\
\text { beginning of } \\
\text { the } \\
\text { experiment } \\
\end{array}$ & $99,55 \pm 1,27$ & $4,83 \pm 0,07$ & $2,22 \pm 0,05$ & $58,36 \pm 0,53$ & $86,0 \pm 4,55$ & $8,33 \pm 0,08$ & 8,0 & 4,2 & 2,9 & 3,2 & 3,6 & 69,1 & 10,4 \\
\hline & 90 days & $110,29 \pm 0,96$ & $5,35 \pm 0,05$ & $2,81 \pm 0,02$ & $78,68 \pm 0,27$ & $43.0 \pm 6,71$ & $8,33 \pm 0,04$ & 2,4 & 5,6 & 1,3 & 3,8 & 19,4 & 60,1 & 7,4 \\
\hline & $\mathrm{P}<$ & 0,05 & 0,05 & 0.01 & 0,05 & 0,05 & 0,01 & & & & & & & \\
\hline
\end{tabular}


Table 7. Results of laboratory examination of large abdominal fluid in experimental cows (AgroBravo cattle $F$ / $x ; M \pm m ; N=30$ )

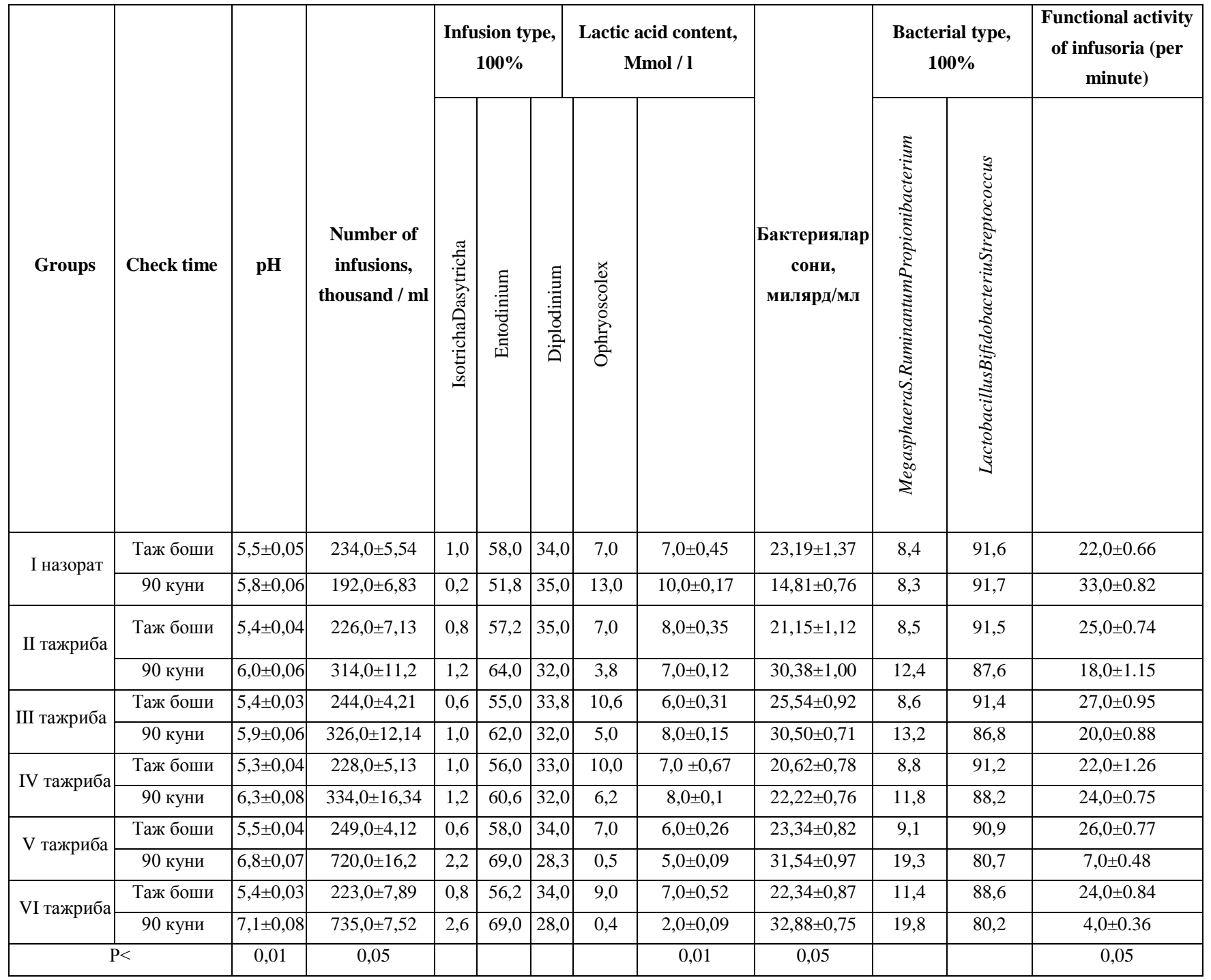

Tables 6 and 7 show the changes in blood and large abdominal fluid samples taken in the beginning and end 90-day trials of cows in the groups of drugs and nutritional supplements used in the experiments.

The hemoglobin level in the blood of the experimental cows averaged $99.65 \pm 1.9 \mathrm{~g} / 1$ at the beginning of the experiment in the I-control group, $98.92 \pm 1.4 \mathrm{~g} / 1$ on the 90th day, and an average of $99.42 \pm 1$ at the beginning of the II-experimental group. $8 \mathrm{~g} / 1$, mean $100.21 \pm 1.35 \mathrm{~g} / 1$ on day 90 , mean $99.26 \pm 1.82 \mathrm{~g} / 1$ at the beginning of experimental group III, mean $100.83 \pm 1.45$ on day $90 \mathrm{~g} / 1$, mean $99.48 \pm 1.84 \mathrm{~g} / \mathrm{l}$ at the beginning of the IV-experimental group, $98.74 \pm 1.29 \mathrm{~g} / 1$ on the 90th day, 99.28 \pm 1 at the beginning of the $\mathrm{V}$-experimental group, $53 \mathrm{~g} / 1$, averaging $101.27 \pm 1.32 \mathrm{~g} / 1$ on day 90 , averaging $99.55 \pm 1.27 \mathrm{~g} / \mathrm{l}$ at the beginning of experimental group VI, and an average of $110.29 \pm 0.96 \mathrm{~g}$ on day 90 . / 1 (norm 99-129 g / 1$)(\mathrm{R}<0.05)$.

The number of erythrocytes in the blood in the I-control group averaged $4.87 \pm 0.04$ million / $\mu 1$ at the beginning of the experiment; An average of $4.53 \pm 0.05$ million / $\mu 1$ on day 90 , an average of $4.75 \pm$ 0.04 million / $\mu$ at the beginning of experimental group II, an average of $5.03 \pm 0.06$ million / $\mu 1$ on day 90, III - in the experimental group the average was $4.66 \pm 0.03$ million / $\mu 1$ at the beginning, on the 90th day the average was $5.01 \pm 0.04$ million / $\mu$, in the IV experimental group the average was $4.81 \pm 0.04$ 
million / $\mu$ at the beginning, 90 - on average $4.41 \pm 0.02$ million / $\mu 1$ per day, on average $4.79 \pm 0.06$ million / $\mu \mathrm{l}$ at the beginning of the $\mathrm{V}$-experimental group, on average on the 90th day $5.02 \pm 0.02 \mathrm{million} / \mu \mathrm{l}$, on average at the beginning of the VI-experimental group4 , $83 \pm 0.07$ million / $\mu$, averaging $5.35 \pm 0.05$ million / $\mu$ l on day 90 (norm 5.5-7.5 million / $\mu \mathrm{l})(\mathrm{R}<0.05)$.

Blood glucose levels in cows were averaged $2.42 \pm 0.08 \mathrm{mmol} / \mathrm{l}$ at the beginning of the experiment in control group I, an average of $2.20 \pm 0.045 \mathrm{mmol} / \mathrm{l}$ at day 90 , and an average of $2.28 \pm 0.08 \mathrm{mmol}$ at the beginning of experimental group II. / 1, averaged $2.41 \pm 0.032 \mathrm{mmol} / 1$ on day 90 , averaged $2.33 \pm$ $0.017 \mathrm{mmol} / \mathrm{l}$ at the beginning of experimental group III, and an average of $2.48 \pm 0.04 \mathrm{mmol} / 1$ on day 90; In the IV experimental group, the mean was $2.36 \pm 0.08 \mathrm{mmol} / 1$ at the beginning, on the 90th day, the mean was $2.23 \pm 0.035 \mathrm{mmol} / \mathrm{l}$, in the 5th experimental group, the mean was $2.29 \pm 0.05 \mathrm{mmol} / 1$ at the beginning, 90- an average of $2.64 \pm 0.02 \mathrm{mmol} / 1$ per day, an average of $2.22 \pm 0.05 \mathrm{mmol} / \mathrm{l}$ at the beginning of the VI-experimental group; On day 90, the mean was $2.81 \pm 0.02 \mathrm{mmol} / \mathrm{l}$ (norm 2.22-3.33 $\mathrm{mmol} / \mathrm{l})(\mathrm{R}<0.01)$.

The decrease in blood glucose during lactation (hypoglycemia) can be explained by the low level of satisfaction of energy needs of cows during lactation.

The total serum protein of the experimental cows averaged $65.13 \pm 1.04 \mathrm{~g} / \mathrm{l}$ at the beginning of the experiment in the I-control group, $52.64 \pm 1.67 \mathrm{~g} / 1$ on the 90th day, and 59.2 at the beginning in the II-experimental group. $\pm 2.28 \mathrm{~g} / \mathrm{l}$, mean $73.14 \pm 1.9 \mathrm{~g} / 1$ on day 90 , mean $58.67 \pm 1.20 \mathrm{~g} / \mathrm{l}$ at the beginning of experimental group III, mean $71.56 \pm 1$ on day $90,38 \mathrm{~g} / 1$, mean $61.37 \pm 1.23 \mathrm{~g} / \mathrm{l}$ at the beginning of the IV experimental group, $54.23 \pm 0.89 \mathrm{~g} / \mathrm{l}$ on the 90th day, mean $65.14 \pm$ at the beginning of the V experimental group $2.95 \mathrm{~g} / 1$, averaging $75.12 \pm 0.31 \mathrm{~g} / 1$ on day 90 , averaging $58.36 \pm 0.53 \mathrm{~g} / 1$ at the beginning of experimental group VI, averaging $78.68 \pm 0$ on day 90, $27 \mathrm{~g} / 1$ (norm - 72-86 g/ l) (R<0.05).

The amount of ketone bodies in the blood of cows was $82.0 \pm 3.54 \mathrm{~g} / 1$ at the beginning of the experiment in the I control group, $99.0 \pm 4.25 \mathrm{~g} / 1$ on the 90 th day, and $85.0 \pm 2$ at the beginning in the II experimental group., $88 \mathrm{~g} / 1$, mean $68.0 \pm 4.82 \mathrm{~g} / 1$ on day 90 , mean $73.0 \pm 3.5 \mathrm{~g} / 1$ at the beginning of experimental group III, mean $64.0 \pm 5.54$ on day $90 \mathrm{~g} / 1$, mean $84.0 \pm 4.92 \mathrm{~g} / 1$ at the beginning of the IV experimental group, $77.0 \pm 4.63 \mathrm{~g} / 1$ on the 90 th day, $93.0 \pm 6$ at the beginning of the V-experimental group, $45 \mathrm{~g} / 1$, mean $58.0 \pm 3.26 \mathrm{~g} / 1$ on day 90 , mean $86.0 \pm 4.55 \mathrm{~g} / 1$ at the beginning of experimental group VI, mean $43.0 \pm 6.71 \mathrm{~g} / 1$ on day $90($ norm $-20-40 \mathrm{~g} / \mathrm{l})(\mathrm{R}<0.05)$.

The number of leukocytes in the blood of cows averaged $7.46 \pm 0.08$ thousand / $\mathrm{ml}$ at the beginning of the experiment in control group I, an average of $7.73 \pm 0.06$ thousand / $\mathrm{ml}$ on day 90 , and an average of $7.24 \pm 0$ at the beginning in experimental group II. 04 thousand / $\mathrm{ml}$, averaging $7.99 \pm 0.08$ thousand $/ \mathrm{ml}$ on day 90 , averaging $8.14 \pm 0.08$ thousand / $\mathrm{ml}$ at the beginning of experimental group III, and an average of $8.24 \pm 0.06$ thousand on day $90 . / \mathrm{ml}$, an average of $7.62 \pm 0.02$ thousand / $\mathrm{ml}$ at the beginning of the IV experimental group, an average of $8.09 \pm 0.05$ thousand / $\mathrm{ml}$ on the 90th day, an average of $7.92 \pm 0.07$ at the beginning of the $\mathrm{V}$-experimental group thousand / $\mathrm{ml}$, averaged $8.18 \pm 0.02$ thousand / $\mathrm{ml}$ on day 90 , averaged $8.33 \pm 0.08$ thousand / $\mathrm{ml}$ at the beginning of experimental group VI, and an average of $8.33 \pm$ 0.04 thousand / $\mathrm{ml}$ on day $90 . \mathrm{ml}$ (norm $4.5-12$ thousand / $\mathrm{ml})(\mathrm{R}<0.01)$.

The $\mathrm{pH}$ of the large abdominal fluid obtained from the experimental cows averaged $5.5 \pm 0.05$ at the beginning of the experiment in the I-control group, $5.8 \pm 0.06$ on the 90th day, and $5.4 \pm 0.04$ at the beginning in the II-experimental group. An average of $6.0 \pm 0.06$ on day 90 , an average of $5.4 \pm 0.03$ at the beginning of experimental group III, an average of $5.9 \pm 0.06$ on day 90 , an average of $5.3 \pm$ at the beginning of experimental group IV 0.04 , mean $6.3 \pm 0.08$ on day 90 , mean $5.5 \pm 0.04$ at the beginning of the Vexperimental group, mean $6.8 \pm 0.07$ on the 90 th day, mean at the beginning of the VI-experimental group $5.4 \pm 0.03$, averaging $7.1 \pm 0.08$ (normal 6.5-7.5) on day $90(\mathrm{P}<0.01)$.

The number of infusions in the large abdominal fluid of cows averaged $234.0 \pm 5.54$ thousand / $\mathrm{ml}$ at the beginning of the experiment in control group I, an average of $192.0 \pm 6.83$ thousand / $\mathrm{ml}$ on day 90 , and an average of $226.0 \pm$ at the beginning in experimental group II. 7.13 thousand / $\mathrm{ml}$, an average of 314.0 
\pm 11.2 thousand / $\mathrm{ml}$ on the 90th day, an average of $244.0 \pm 4.21$ thousand / $\mathrm{ml}$ at the beginning of the III experimental group, an average of $326.0 \pm 12$ on the 90th day, 14 thousand / $\mathrm{ml}$, on average $228.0 \pm 5.13$ thousand / $\mathrm{ml}$ at the beginning of the IV experimental group, on average on the 90th day $334.0 \pm 16.34$ thousand / $\mathrm{ml}$, on average at the beginning of the V-experimental group $249.0 \pm 4,12$ thousand / $\mathrm{ml}$, averaging $720.0 \pm 16.2$ thousand / $\mathrm{ml}$ on the 90th day, an average of $223.0 \pm 7.89$ thousand / $\mathrm{ml}$ at the beginning of the VI experimental group, an average of $735.0 \pm 7.52$ on the 90 th day thousand / $\mathrm{ml}$ (norm from 700 thousand to $1-2$ million / ml $)(\mathrm{P}<0.05)$.

At the beginning of the experiment in the I-control group of infusoria in the large abdominal fluid of experimental cows averaged Isotricha, Dasytrichaturkumi averaged $1 \% / \mathrm{ml}$, Entodinium turkumio average 58\% / ml, Diplodinium turkumio average 34\% / ml, Ophryoscolexturkumio average $7 \%$ / $\mathrm{ml}$, on day 90 average $0.2 \%$ / ml, Entodinium turkumio average $51 \%$ / ml, Diplodinium turkumio average $35 \% \mathrm{ml}$, Ophryoscolexturkumio average $13 \% / \mathrm{ml}$, at the beginning of the II experimental group average Isotricha, Dasytrichaturkumi average $0.8 \% / \mathrm{ml}$, Entodinium turkumio average $57 \% / \mathrm{ml} \mathrm{ml}$, Diplodinium turkumio average $35 \% / \mathrm{ml}$, Ophryoscolexturkumio average $7 \% / \mathrm{ml}$, 90-day average Isotricha, Dasytrichaturkumi average $1.2 \% / \mathrm{ml}$, Entodinium turkumio average $54 \%$ / $\mathrm{ml}$, Diplodinium turkumio average $32 \% / \mathrm{ml}$, Ophryoscolextur 3\% $\mathrm{ml}$, the average Isotricha at the beginning of the III experimental group, Dasytrichaturkumi average $0.6 \%$ / $\mathrm{ml}$, Entodinium turkumio average $55 \%$ / ml, Diplodinium turkumio average 33\% / ml, Ophryoscolexturkumio average 10.6\% / $\mathrm{ml}$, average 90 days Isotricha, Dasytric haturkumi average $1 \%$ / $\mathrm{ml}$, Entodinium turkumio average $62 \%$ / $\mathrm{ml}$, Diplodinium turkumio average $32 \%$ / $\mathrm{ml}$, Ophryoscolexturkumio average $5 \% / \mathrm{ml}$, at the beginning of the IV experimental group average Isotricha, Dasytrichaturkumi average 1\% / ml, Entodinium turkumio average 56\% Diplodinium turkumio average $33 \% / \mathrm{ml}$, Ophryoscolexturkumio average 10\% / ml, 90-day average Isotricha, Dasytrichaturkumi average $1.2 \% / \mathrm{ml}$, Entodinium turkumio average $60.6 \%$ / $\mathrm{ml}$, Diplodinium turkumio average $32 \% / \mathrm{ml}$, Ophryoscolexturio $6 \% / \mathrm{ml} \mathrm{ml}$, average Isotricha at the beginning of the V-experimental group, Dasytrichaturkumi average $0.6 \%$ / $\mathrm{ml}$, Entodinium turkumio average $58 \%$ / ml, Diplodinium turkumio average 34\% / ml, Ophryoscolexturkumio average 7\% / ml, 90-day average Isotricha, Dasytrichaturkumi $2 \%$ / ml, Entodinium turmeric average $69 \%$ / $\mathrm{ml}$, Diplodinium turmeric average $28.3 \%$ / ml, Ophryoscolexturkumio average $0.5 \% / \mathrm{ml}$, at the beginning of the VI experimental group average Isotricha, Dasytrichaturkumi average $0.8 \%$ / ml, Entodinium turkumio average 56, 2\% / ml, Diplodinium turkumio average $34 \% / \mathrm{ml}$, Ophryoscolext urkumio average 9\% / ml, 90-day average Isotricha, Dasytrichaturkumi average $2.6 \%$ / ml, Entodinium turkumio average $69 \% / \mathrm{ml}$, Diplodinium turkumio average $28 \% / \mathrm{ml}$, Ophryoscolexturkumio average $0.4 \% / \mathrm{ml}$.

The type of infusoria was studied mainly on the basis of data from the authors (I. G. Pivnyak, B.V. Tarakanov) [7]. Our investigations revealed the presence of Isotricha, Dasytricha, Entodinium, Diplodinium, and Ophryoscolex species in the large abdominal fluid of farm cows, but it was found that these infusoria underwent drastic changes in body composition and proportions.

In the study of the amount of lactic acid in the large abdominal fluid from cows, the mean in the control group I was $7.0 \pm 0.45 \mathrm{Mmol} / 1$ at the beginning of the experiment, the average on the 90th day was $10.0 \pm 0.17 \mathrm{Mmol} / 1$, in the experimental group II $8.0 \pm 0.35 \mathrm{Mmol} / 1$, mean $7.0 \pm 0.12 \mathrm{Mmol} / 1$ on day 90 , mean $6.0 \pm 0.31 \mathrm{Mmol} / 1$ at the beginning of experimental group III, mean 8.0 on day $90 \pm 0.15$ $\mathrm{Mmol} / 1$, mean $7.0 \pm 0.67 \mathrm{Mmol} / 1$ at the beginning of experimental group IV, mean $8.0 \pm 0.1 \mathrm{Mmol} / 1$ at day 90 , mean 6 at the beginning of experimental group V, $0 \pm 0.26 \mathrm{Mmol} / 1$, mean 5.0 $\pm 0.09 \mathrm{Mmol} / 1$ on day 90 , mean $7.0 \pm 0.52 \mathrm{Mmol} / 1$ at the beginning of experimental group VI, mean $2.0 \pm$ on day 900.09 $\mathrm{Mmol} / \mathrm{l}(1.5-5.0 \mathrm{Mmol} / 1$ in healthy animals $)(\mathrm{P}<0.01)$.

The number of bacteria in the large abdominal fluid of cows in the groups averaged $23.19 \pm 1.37$ billion / $\mathrm{ml}$ at the beginning of the experiment in control group I, an average of $14.81 \pm 0.76 \mathrm{billion} / \mathrm{ml}$ on day 90 , and an average of 21 at the beginning in experimental group II. $15 \pm 1.12$ billion / ml, mean 30.38 \pm 1.00 billion / $\mathrm{ml}$ on day 90 , mean $25.54 \pm 0.92$ billion / $\mathrm{ml}$ at the beginning of experimental group III, mean $30.50 \pm 0$ on day 90,71 billion / ml, mean $20.62 \pm 0.78$ billion / $\mathrm{ml}$ at the beginning of the IV experimental group, $22.22 \pm 0.76$ billion / $\mathrm{ml}$ at the beginning of the 90th day, $23.34 \pm$ average at the 
beginning of the V-experimental group 0.82 billion / $\mathrm{ml}$, averaging $31.54 \pm 0.97$ billion / $\mathrm{ml}$ on day 90, an average of $22.34 \pm 0.87$ billion / $\mathrm{ml}$ at the beginning of Experiment Group VI, and an average of $32.88 \pm 0$ on day 90, 75 billion / $\mathrm{ml}$ (Georgievsky, 1990, normally 6 to 40 billion) $(\mathrm{P}<0.05)$.

Bacteria in the large abdominal fluid content of experimental cows in the I-control group at the beginning of the experiment were $8.4 \%$ of average lactic acid-absorbing bacteria, $91.6 \%$ of lactic acidsynthesizing bacteria, $8.3 \%$ of average lactic acid-absorbing bacteria on day 90 , lactic acid-synthesizing bacteria $91.7 \%$, in the II experimental group at the beginning of the average lactic acid assimilation bacteria $8.5 \%$, lactic acid synthesis bacteria $91.6 \%$, on the 90th day the average lactic acid assimilation bacteria $12.4 \%$, lactic acid synthesis bacteria $87.6 \%$, III In the experimental group, the average lactic acid-absorbing bacteria was $8.6 \%$, lactic acid-synthesizing bacteria $91.4 \%$, on the 90 -day average lactic acid-absorbing bacteria $13.2 \%$, lactic acid-synthesizing bacteria $86.8 \%$. acid-assimilating bacteria $8.8 \%$, lactic acidsynthesizing bacteria $91.2 \%$, average lactic acid-absorbing bacteria on day $9011.8 \%$, lactic acid synthesizing bacteria $88.2 \%$, ni, in the V-experimental group at the beginning of the average lactic acidabsorbing bacteria $9.1 \%$, lactic acid-synthesizing bacteria $90.9 \%$, on the 90th day the average lactic acidabsorbing bacteria $19.3 \%$, lactic acid synthesizing bacteria $80.7 \%$, ni, in the VI experimental group at the beginning of the average lactic acid assimilation bacteria $11.4 \%$, lactic acid synthesizing bacteria $88.6 \%$, on the 90th day the average lactic acid assimilation bacteria $19.8 \%$, milk acid-synthesizing bacteria accounted for $80.2 \%$.

The functional activity of infusoria in the large abdominal fluid of cows averaged $22.0 \pm 0.66$ minutes at the beginning of the experiment in the control group I, an average of $33.0 \pm 0.82$ minutes at the beginning of the 90th day, and an average of $25.0 \pm 0.74$ minutes at the beginning of the II experimental group. mean $18.0 \pm 1.15$ minutes, mean $27.0 \pm 0.95$ minutes at the beginning of experimental group III, mean $20.0 \pm 0.88$ minutes at the beginning of day 90 , mean $22.0 \pm 1.26$ minutes at the beginning of experimental group IV, mean 90 at the beginning $24.0 \pm 0.75$ minutes, mean $26.0 \pm 0.77$ minutes at the beginning of the $\mathrm{V}$-experiment group, mean $7.0 \pm 0.48$ minutes at the beginning of the 90th day, mean 24.0 \pm 0.84 minutes at the beginning of the VI-experimental group, mean 90 days $4.0 \pm 0.36$ minutes (norm 3 minutes $)(\mathrm{P}<0.05)$.

In addition to traditional therapies for the treatment of chronic metabolic acidosis in cows, $20 \mathrm{ml}$ of the drug Multivit + mineral was administered intramuscularly every 15 days. The microorganisms Saccharomyces cerevisie and Aspergilius oryzae in $\mathrm{NaHCO}_{3}$ and special premix, which are constantly added to the feed, enhance the digestive processes in the large intestine of cows, as well as the development of beneficial species of infusoria and bacteria that are important for cows; resulting in a return of the number of microorganisms to normal and, as a result, an improvement in the productivity and health performance of cows.

In order to eliminate the metabolic factors that occur during acidosis, treatments aimed at restoring liver function were performed. For this purpose, an ampoule form of Essentsiale forte was used. This drug was administered intravenously once a day for 10 to $5 \mathrm{ml}$ per cow.

It was also found that it is advisable to focus on adjusting the energy-protein ratio of the ration when feeding cows (cow rats. 1 o.b. 100-120 $\mathrm{g}$ of digestible protein and 80-100 $\mathrm{g}$ of sugar, and the sugarprotein ratio should be $0.8-1.2$ ).

\section{Conclusion}

1. In the diagnosis of large abdominal acidosis in pedigree cows in the acute phase of the disease should take into account the type of diet, nutrition and quality of nutrients, as well as clinical examination to determine the decrease in appetite in the animal, decreased motility of the large abdominal wall. at the expense of acids), it is advisable to conduct laboratory tests to determine the number of infusoria and beneficial bacteria in it and changes in species composition. 
2. In addition to the above-mentioned clinical and laboratory tests in the chronic form of large abdominal acidosis should be taken into account metabolic disorders and morpho-functional status of the liver, which are the pathogenetic consequences of the disease.

3. The principle of treatment of large abdominal acidosis in cows should represent the elimination not only of digestive processes in the anterior gastrointestinal tract, but also of profound metabolic and hepatopathic changes.

\section{References}

[1] Chaucheyras-Durand, F. Effects of active dry yeast on the rumen microbial ecosystem: past, present and future / F. Chaucheyras-Durand, N.D. Walker, A. Bach // Animal. Feed. Sci. Technol., 2008, 145:526.Gozho, G. N. Rumen lipopolysaccharide and inflammation during grain adaptation and subacuteruminal acidosis in steers / G.N. Gozho, D.O. Krause, J.C. Plaizier // J. Dairy Sci., 2006, 89:4404-4413.

[2] Gordon, F. J. The effect of forage digestibility and type of concentrate on nutrient utilization for lactating dairy cattle / F.J. Gordon, M.G. Porter // J. Dairy Res., 1995, 62:15-27.

[3] Aizahal, O. Ruminal temperature may aid in the detection of subacute ruminal acidosis / O. AIZahal, O. Kebreab, J. France, M. Fraetschel, B.W. McBride // J. Dairy Sci., 2008, 91: 202-207.

[4] Bakirov B. (2015) Internal non-communicable diseases of animals. Study guide. Samarkand. 45145.147. - p. 149.

[5] Ferraretto, L. F. Effect of dietary supplementation with live-cell yeast at two dosages on lactation performance rumen fermentation, and total-tract nutrient digestibility in dairy cows / L.F. Ferraretto, R.D. Shaver, S.J. Bertics // J. Dairy Sci., 2012, 95:4017-4028.

[6] Booth, C. J. Effect of lameness on culling in dairy cows / C.J. Booth, L.D. Warnick, Y.T. Grohn, D.O. Maizon, C.L. Guard, D. Janssen // J. Dairy Sci., 2004, 87: 4115-4122.

[7] Pivnyak I.G., Tarakanov B.V. (1982) Microbiology digestion of ruminants. MOSCOW "KOLOS”. pp. $145,151$.

\section{Copyrights}

Copyright for this article is retained by the author(s), with first publication rights granted to the journal.

This is an open-access article distributed under the terms and conditions of the Creative Commons Attribution license (http://creativecommons.org/licenses/by/4.0/). 